International Journal of Business Management and Economic Review

Vol. 4, No. 04; 2021

ISSN: 2581-4664

\title{
THE EFFECT OF CORPORATE ENTREPRENEURSHIP AND ORGANIZATIONAL CULTURE ON SUPPLY CHAIN MANAGEMENT AND ITS IMPACT ON THE OPERATIONAL PERFORMANCE OF LOGISTIC COMPANIES IN BANDA ACEH
}

\author{
Zulfandi, Nasir and A. Sakir \\ Management Department, Universitas Syiah Kuala, Indonesia \\ http://doi.org/10.35409/IJBMER.2021.3284
}

\begin{abstract}
This study intends to examine the effect of corporate entrepreneurship and organizational culture on supply chain management and its impact on the operational performance of logistics companies in Banda Aceh. The population of this study was all employees at logistic companies in Banda Aceh, amounting to 195 people, and the sample taken was as many as the population. Data were analyzed by Structural Equation Modeling (SEM). The results conclude that corporate entrepreneurship significantly affects supply chain management, organizational culture significantly affects supply chain management, supply chain management significantly affects operational performance, corporate entrepreneurship significantly affects operational performance, organizational culture significantly affects operational performance, supply chain management mediates the influence of corporate entrepreneurship on operational performance, and supply chain management mediates the influence of organizational culture on operational performance. From these results, it also explains that supply chain management is proven to function as a partial mediator in the research model. These findings reveal that in modeling the operational performance of logistics companies, corporate entrepreneurship and organizational culture are the right predictor variables to be in better shape so that they can have an impact on increasing the effectiveness and efficiency of supply chain management and affect the increase in operational performance. Further research is expected to add other variables such as Total Quality Management and self-efficacy of company employees in other industrial sectors.
\end{abstract}

Keyword: Corporate Entrepreneurship, Organizational Culture, Supply Chain Management, Operational Performance.

\section{INTRODUCTION}

Technological advances in logistics have developed rapidly and have given birth to many new companies that offer freight forwarding services by land, air, and sea. The increasing demand from consumers for logistics service needs requires companies to have competent resources. This causes companies to be required to think about the sustainability of their company so that services can be produced professionally and are trusted as competent and timely logistics services.

By establishing good relationships and providing the best quality service, it provides a great opportunity for logistics companies to become the community's choice. The sender of the 


\section{International Journal of Business Management and Economic Review}

Vol. 4, No. 04; 2021

ISSN: 2581-4664

goods will have an interest in ensuring that the selected logistics service is known by the public, this needs to be done by the company with communicative communications.

The occurrence of price disparities between regions is one indication that there are still problems in logistic operational performance. In the Indonesian context, this convergence has not been seen in at least the last four years. Based on data from the Directorate General of Domestic Trade, in 2015 - 2019, the development of the level of price disparity has not shown a pattern of persistent decline, wherein certain years it has decreased, while in other years it has increased. This shows that the policy to reduce price disparities has not produced optimal results. The price disparity between regions is not only for staple foodstuffs but for other goods considered to have strategic value, such as cement. Aceh Province conducts purchase transactions outside the province with a transaction value of 6.2 trillion rupiahs. Where 4.2 trillion rupiahs were purchases from the province of North Sumatra. In addition, almost all of the sales transaction value was also sold to North Sumatra province, which reached 9.7 trillion rupiahs.

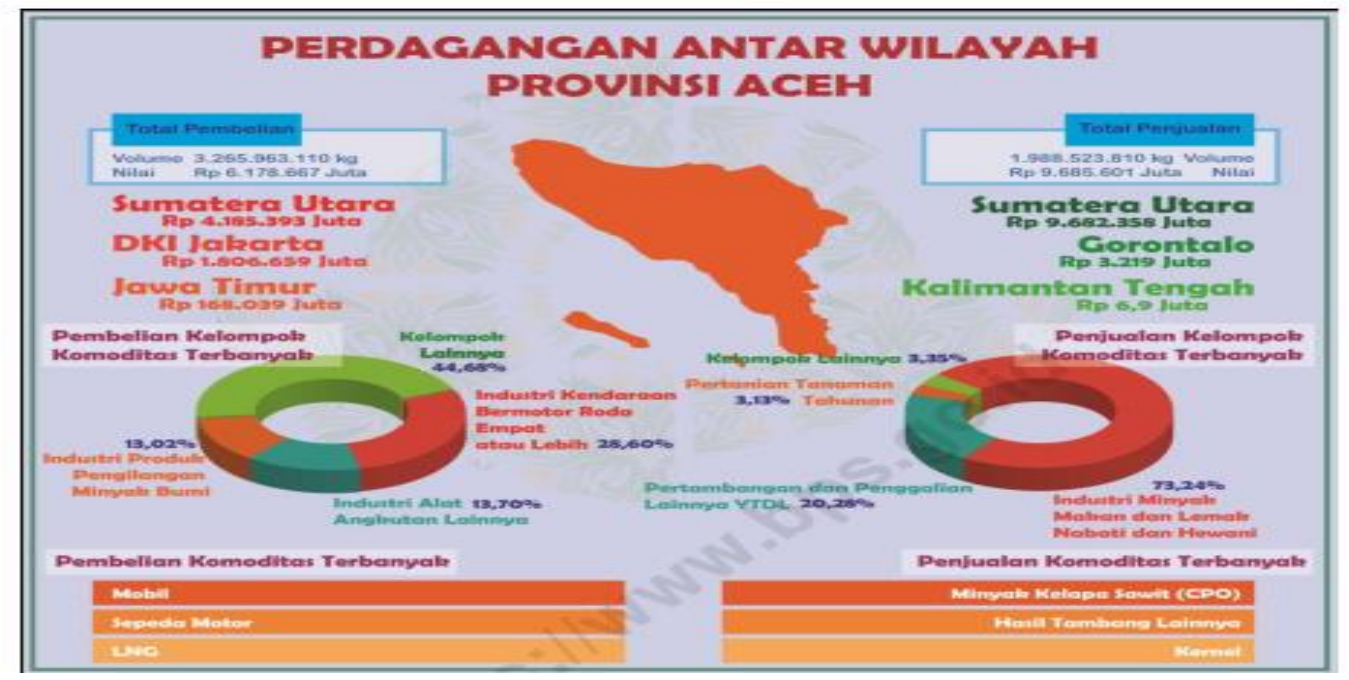

Figure 1. Inter-Regional Trade of Aceh Province Source: BPS, RI (2019)

Several industrial commodity groups are commodity groups that dominate purchase transactions from outside Aceh province, where cars, motorbikes, and LNG are the three main commodities in purchase transactions from outside Aceh province, while palm oil (CPO) is the most sold commodity. outside the province of Aceh. Most of the shipments of commodities purchased from outside and sold outside Aceh province used land transportation, which reached almost $97.84 \%$. In addition, there are also around $1.34 \%$ each of the use of water transportation modes of transportation and $0.82 \%$ of air transportation for the delivery of commodities purchased and or sold from and outside the island of Sumatra (BPS, RI 2019).

In this research, the author will discuss the internal problems of logistics companies operating in the sea route. Because the sea route is still minimally used, even though the sea route is a safer route than land, and the shipping costs are cheaper, the volume of goods transported is greater and is able to cross islands, countries, and even continents. Efficiency is 


\section{International Journal of Business Management and Economic Review}

Vol. 4, No. 04; 2021

ISSN: 2581-4664

also reflected in the use of fuel oil (BBM). Sea transportation is used to reduce logistics costs and price disparities in areas especially in western Indonesia such as Aceh. However, this is inversely proportional to the fact that occurred in Aceh where the majority of shipments of goods sent were by land. Several logistics companies in Banda Aceh that also use sea routes include PT MGM, PT Faizir Rizki, PT Fanindo Internasional Logistik, PT Anugerah Jaya Abadi, and PT Burak Kargo.

The problems faced by logistics companies in the city of Banda Aceh have so far not increased their performance every year, the volume of goods shipments has decreased every year. There was an error in the delivery of goods, and the goods sent had a lot of trouble and the shipping costs were expensive and the goods were not sent on time. In general, many factors can affect the company's operational performance. However, this research tries to measure the most dominant factors affecting the operational performance of logistics companies, including Supply Chain Management, Corporate Entrepreneurship and organizational culture.

\section{LITERATURE STUDY}

\section{Operational Performance}

(Wibowo, 2016)revealed, performance can be viewed as a process or result of work. Performance is the process of how work takes place to achieve work results. (Daft, 2010)mentioning operational performance is a management field that specializes in the production of goods and services, and uses special tools and techniques to solve production problems. Another opinion(Rahadi, 2012)discloses that the company's operational performance is something that the company produces in a certain period by referring to the standards that have been determined in the company's operational activities.

Meanwhile(Handoko, 2016)stated that operational performance is the implementation of managerial activities that are carried out in the selection, design, renewal, operation and supervision of production systems. In this research, the measurement of operational performance uses indicators as disclosed by(Handoko, 2016)namely productivity level, product error rate, warranty or warranty costs, quality costs and timeliness.

\section{Supply Chain Management}

Supply chain managementwas first used to describe the logistics between internal and external organizational functions for managing the flow of materials and information across organizational boundaries(Cooper \& Ellram, 1993). The supply chain is the management of various functions performed by an organization including procurement and purchasing, manufacturing, logistics activities, and strong coordination between supply chain partners(Hashim, Baig, Amjad, Nazam, \& Akram, 2020).

Supply chain managementis an approach used to achieve a more efficient integration of various organizations from suppliers, manufacturers, distributors, retailers, and customers(Simchi-Levi, Kaminsky, \& Simchi-Levi, 2004).Meanwhile(Heizer \& Render, 2015)In his book, it is explained that SCM is an activity that describes the coordination of all supply chain activities. The purpose of supply chain management is to integrate the company's main business processes starting from the upstream and downstream relationships even to the endusers(Rachbini, 2016).

Thus, it can be concluded that supply chain management is one of the routines carried out 


\section{International Journal of Business Management and Economic Review}

Vol. 4, No. 04; 2021

ISSN: 2581-4664

by companies in producing products, distributing them to consumers' customers effectively and efficiently. In this research, the measurement of supply chain management can be measured using four dimensions as disclosed by(Miguel \& Brito, 2011)namely the dimension of information sharing with indicators (1) sharing of information in terms of financial, production, and design; (2) exchange information on an ongoing basis; (3) information can help all parties concerned. The dimension of a long-term relationship with indicators (1) long-term projects is the basis of relationships with suppliers, (2) cooperation is the basis for long-term relationships, (3) relationships last for a long time. The cooperation dimension with indicators (1) discusses planning and sales forecasting, (2) cooperation is determined based on objective conditions, (3) enhances sustainable relationships. The dimension of the process integration with indicators (1) priority logistic activity, (2) logistic activity has good integrity, (3) effective material flow.

\section{Organizational culture}

Culture is the norms and values that direct the behavior of organizational members(Luthans, 2013). Organizational culture represents patterns of shared beliefs and values that guide corporate behavior(Cadden, Marshall, \& Cao, 2013). Culture also reflects the thinking of organizational members, openness and transparency which are very important in building supply chain relationships. Organizational culture is defined as the assumptions, values, and beliefs that are shared among organizational members(Cao, Huo, Li, \& Zhao, 2015). Cultural compatibility among supply chain partners is an important factor in supply chain integration efforts. Companies that share the same cultural attributes increase communication efforts, trust, and mutual exchange of knowledge(Porter, 2019). Organizational culture is very important, because when organizational culture alignment does not exist, the company may not achieve its integration and performance improvement goals(Cao et al., 2015).

Based on the above definitions, it can be concluded that organizational culture is the value or belief that employees have in carrying out their duties in supplying products from producers to consumers. In this research, the measurement of organizational culture uses indicators(Robbins \& Judge, 2017)namely innovation and courage to take risks, attention to detail, results-oriented, human-oriented, team-oriented, aggressiveness and stability.

\section{Corporate Entrepreneurship}

Corporate entrepreneurship refers to behavioral intentions and organizational behavior that leads to deviations from other forms of business conduct in general(Antoncic \& Hisrich, 2003). Entrepreneurship is based on individuals starting new ventures, now extended to the corporate level(Kazanjia, Drazin, \& Glynn, 2017).In today's environment, corporate entrepreneurship is the most important element of any business. Intention to Corporate Entrepreneurship is very important in a competitive environment. Intention to Corporate Entrepreneurship generates valuable ideas to improve business performance(Mwaniki \& Ondiek, 2018). Corporate Entrepreneurship is a mechanism used to grow new businesses, goods, services or processes in running an organization to generate competitive advantages and find new income-generating opportunities through entrepreneurial thinking and practical approaches(Pham, Nguyen, \& Huy, 2020).Logistics companies must focus on Corporate Entrepreneurship to solve various problems related to entrepreneurship(Chienwattanasook, Wattanapongphasuk, Prianto, \& Jermsittiparsert, 2019). 


\section{International Journal of Business Management and Economic Review}

Vol. 4, No. 04; 2021

ISSN: 2581-4664

Based on the above definitions, it can be concluded that Corporate Entrepreneurship is entrepreneurship in an organization that refers to the intention of behavior and organizational behavior to be more active, innovative, aggressive and proactive in carrying out work to create better company performance. In this research, the measurement of corporate entrepreneurship is measured using indicators as disclosed by(Dess \& Lumpkin, 2005; Pham et al., 2020) namelycreation, innovation, risk undertake, general management, dan performance intention.

\section{Conceptual Framework}

This research conceptual framework can be described as follows :

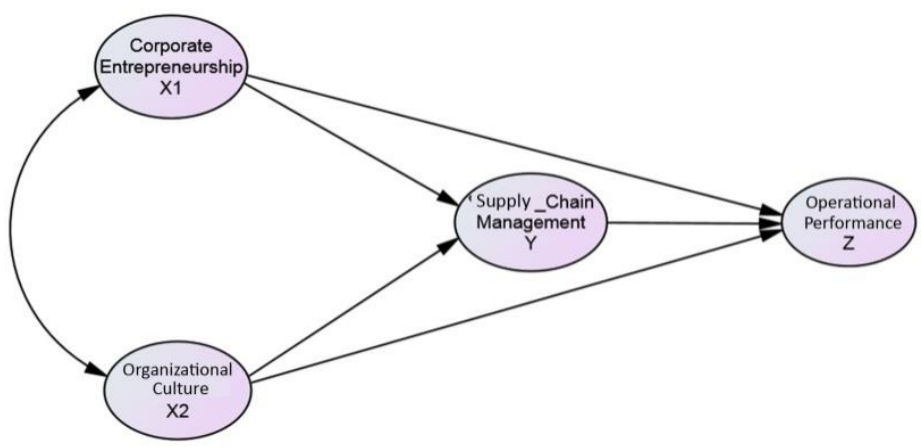

Figure 2. Conceptual Framework

H1 : Corporate Entrepreneurship significantly affects Supply Chain Management

H2 : Organizational Culture significantly affects Supply Chain Management

H3 : Supply Chain Management significantly affects Operational performance

$\mathrm{H} 4$ : Corporate Entrepreneurship significantly affects operational performance

H5 : Organizational Culture significantly affects Operational Performance

H6 : Corporate Entrepreneurship significantly affects Operational Performance through Supply Chain Management

H7 : Organizational Culture significantly affects Operational Performance through Supply Chain Management

\section{RESEARCH METHODS}

This research was conducted at a logistics company in Banda Aceh. Meanwhile, the object of research is corporate entrepreneurship, organizational culture, supply chain management, and company operational performance. The population used in this research is all employees at logistics companies in Banda Aceh, as shown in Table 1 below:

Table 1. List of Logistics Companies in Banda Aceh

\begin{tabular}{|l|l|l|}
\hline NO & Company Name & Amount \\
\hline 1 & PT MGM & 28 \\
\hline 2 & PT Faizir Rizki & 25 \\
\hline
\end{tabular}




\section{International Journal of Business Management and Economic Review}

Vol. 4, No. 04; 2021

ISSN: 2581-4664

\begin{tabular}{|l|l|l|l|}
\hline \hline 3 & PT Fanindo Internasional Logistik & 14 \\
\cline { 2 - 4 } 4 & PT Anugerah Jaya Abadi & 10 \\
\hline 5 & PT Burak Kargo & 12 \\
\hline 6 & Karisma selaras Indotama & 15 \\
\hline 7 & PT. Graha Tuah & 32 \\
\hline 8 & PT. Bumi Asia & 21 \\
\hline 9 & TAM Cargof & 20 \\
\hline 10 & PT. Rimaco Utama Cemerlang & 18 \\
\hline \multicolumn{2}{|l|}{ TOTAL } & $\mathbf{1 9 5}$ \\
\hline
\end{tabular}

Source: Data processed (2020)

The sample taken was as many as the population. Data were collected using a questionnaire and measured using a Likert scale. Data were analyzed using Structural Equation Modeling (SEM) through the AMOS 22 application program. The specifications of the research model in the series of equations are as follows:

$\eta_{1}=\gamma 1.1 \xi 1+\gamma 1.2 \xi 2+\zeta 1$

$\eta_{2}=\gamma 2.1 \xi 1+\gamma 2.2 \xi 2+\beta 21 \eta_{1}+\zeta 2$

or

Supply Chain Management $=\gamma 1.1$ Corporate entrepreneurship $+\gamma 1.2$ Organizational Culture + $\zeta 1$

Operational Performance $=\gamma 2.1$ Corporate entrepreneurship $+\gamma 2.2$ Organizational Culture + B2.1 Supply Chain Management $+\zeta 2$

To test the indirect effect, the researcher implemented the concept developed by(Baron \& Kenny, 1986)which can be explained as follows.

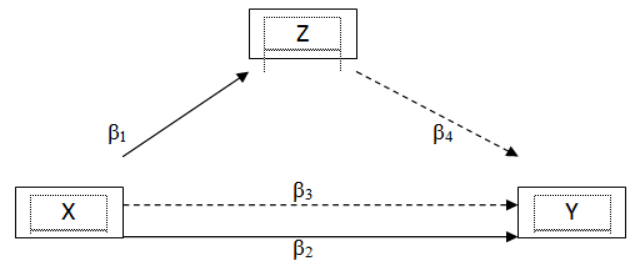

Figure 3. Techniques for testing the mediation effect

Equation $1: Z=\beta_{1} X$

Equation 2: $Y=\beta_{2} X$

Equation 3: $Y=\beta_{3} X+\beta_{4} X$ $\begin{array}{ll}\longrightarrow & \beta_{1} \text { Must be Significant } \\ & \quad \beta_{4} \text { Must be Significant }\end{array}$

-- $\quad \beta_{3}$ Must be Significant; andif $\beta 2$ is not significant, this will mean that there is a fully mediated effect; and if $\beta 2$ is significant, there will be a partially mediated effect.

\section{RESULT}

Direct Effect

The structural model that explains the effect between variables is presented in the following diagram: 
International Journal of Business Management and Economic Review

Vol. 4, No. 04; 2021

ISSN: 2581-4664

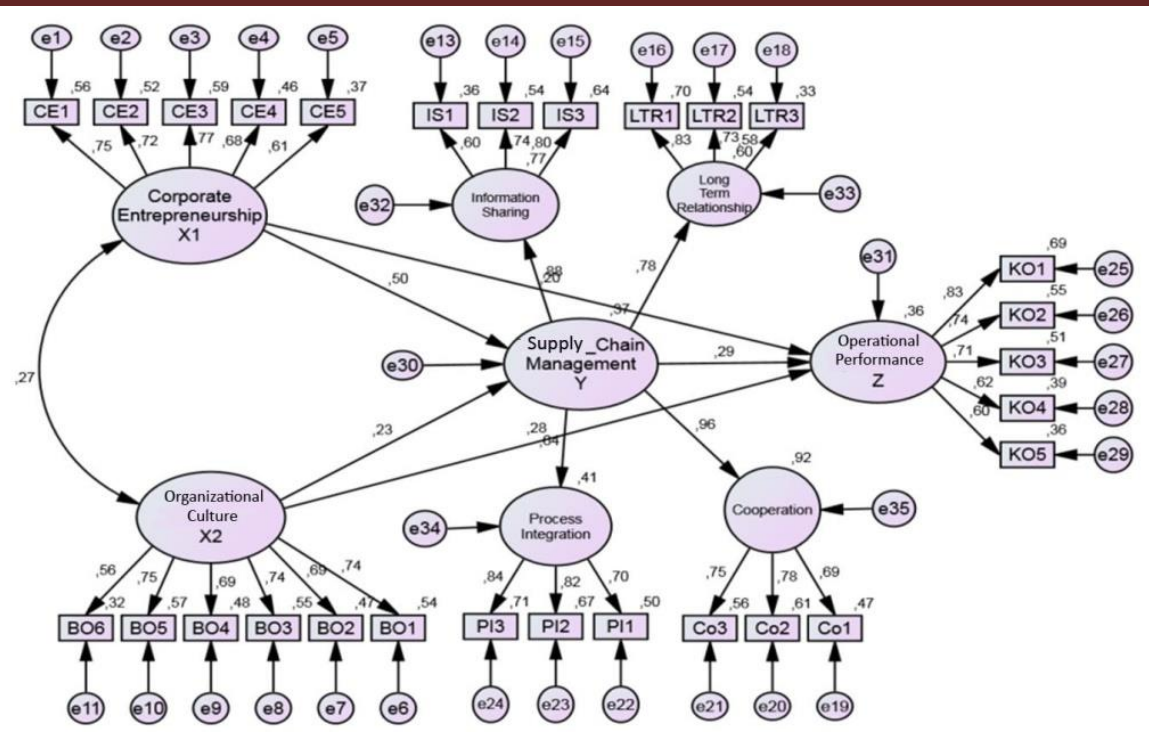

Figure 3. Test Results

The test results of the direct effect hypotheses after fulfilling the SEM assumptions are clearly shown in the following table.

Table 2. Hypothesis Test Results

\begin{tabular}{|c|c|c|c|c|c|c|c|}
\hline \multirow[b]{2}{*}{ Endogen Variable } & & \multirow[b]{2}{*}{ Exogen Variable } & \multicolumn{2}{|l|}{ Estimate } & \multirow{2}{*}{$\begin{array}{l}\text { S. } \\
\text { E. }\end{array}$} & \multirow{2}{*}{ R. } & \multirow[b]{2}{*}{$\mathbf{P}$} \\
\hline & & & $\begin{array}{l}\text { Standard } \\
\text { ized }\end{array}$ & $\begin{array}{l}\text { Unstandar } \\
\text { dized }\end{array}$ & & & \\
\hline $\begin{array}{l}\text { Supply_Chain_Manag } \\
\text { ement_Y }\end{array}$ & $\begin{array}{ll}<- \\
-\end{array}$ & $\begin{array}{l}\text { Corporate_Entrepreneu } \\
\text { rship_X1 }\end{array}$ & 0.503 & 0.345 & $\begin{array}{l}0.07 \\
0\end{array}$ & $\begin{array}{l}4.95 \\
0\end{array}$ & ** \\
\hline $\begin{array}{l}\text { Supply_Chain_Manag } \\
\text { ement_Y }\end{array}$ & $\begin{array}{ll}<- \\
-\end{array}$ & $\begin{array}{l}\text { Organizational_Cultur } \\
\text { e_X2 }\end{array}$ & 0.233 & 0.161 & $\begin{array}{l}0.05 \\
7\end{array}$ & $\begin{array}{l}2.84 \\
0\end{array}$ & .00 \\
\hline $\begin{array}{l}\text { Operasional_Performa } \\
\text { nce_Z }\end{array}$ & $\begin{array}{ll}<- \\
-\end{array}$ & $\begin{array}{l}\text { Supply_Chain_Manag } \\
\text { ement_Y }\end{array}$ & 0.288 & 0.510 & $\begin{array}{l}0.18 \\
4\end{array}$ & $\begin{array}{l}2.76 \\
6\end{array}$ & .00 \\
\hline $\begin{array}{l}\text { Operasional_Performa } \\
\text { nce_Z }\end{array}$ & $\begin{array}{ll}<- \\
-\end{array}$ & $\begin{array}{l}\text { Corporate_Entrepreneu } \\
\text { rship_X1 }\end{array}$ & 0.201 & 0.244 & $\begin{array}{l}0.11 \\
6\end{array}$ & $\begin{array}{l}2.10 \\
8\end{array}$ & .03 \\
\hline $\begin{array}{l}\text { Operasional_Performa } \\
\text { nce_Z }\end{array}$ & \begin{tabular}{|l|}
$<--$ \\
-
\end{tabular} & $\begin{array}{l}\text { Organizational_Cultur } \\
\text { e_X2 }\end{array}$ & 0.281 & 0.344 & $\begin{array}{l}0.10 \\
0\end{array}$ & $\begin{array}{l}3.42 \\
3\end{array}$ & $\begin{array}{l}* * \\
*\end{array}$ \\
\hline Information_Sharing & $\begin{array}{l}<- \\
-\end{array}$ & $\begin{array}{l}\text { Supply_Chain_Manag } \\
\text { ement_Y }\end{array}$ & 0.876 & & & & \\
\hline $\begin{array}{l}\text { Long_Term_Relations } \\
\text { hip }\end{array}$ & \begin{tabular}{|l|}
$<--$ \\
- \\
\end{tabular} & $\begin{array}{l}\text { Supply_Chain_Manag } \\
\text { ement_Y }\end{array}$ & 0.776 & & & & \\
\hline Cooperation & \begin{tabular}{|l|}
$<--$ \\
- \\
\end{tabular} & $\begin{array}{l}\text { Supply_Chain_Manag } \\
\text { ement_Y }\end{array}$ & 0.959 & & & & \\
\hline Process_Integration & $<--$ & Supply_Chain_Manag & 0.640 & & & & \\
\hline
\end{tabular}


International Journal of Business Management and Economic Review

Vol. 4, No. 04; 2021

ISSN: 2581-4664

\begin{tabular}{|l|l|l|l|l|l|l|l|}
\hline \hline \multirow{2}{*}{ Endogen Variable } & \multirow{4}{|l|}{} & \multicolumn{2}{|l|}{ Estimate } & S. & $\begin{array}{l}\text { C. } \\
\text { R. }\end{array}$ & P \\
\cline { 3 - 5 } & & Exogen Variable & $\begin{array}{l}\text { Standard } \\
\text { ized }\end{array}$ & $\begin{array}{l}\text { Unstandar } \\
\text { dized }\end{array}$ & E. & Red \\
& & ement_Y & \multicolumn{2}{|l}{} \\
\hline
\end{tabular}

Source: Primary data, 2021 (processed)

From the findings in Table 2, it revealsthe explanations as follows:

1. H1: The result of testing the influence of Corporate Entrepreneurship on the Supply Chain Management shows a CR value of 4.950 and a probability value (p-value) of *** or 0.000 less than 0.05 . These values explain that the test results are sufficient to accept $\mathrm{H} 1$, namely the CR value which is already higher than the 1.96 value, and the p-value which is already lower than 0.05. So it can be said that the influence of Corporate Entrepreneurship on supply chain management is significant. The magnitude of the coefficient of influence of Corporate Entrepreneurship on supply chain management can be seen from the model image and the Standardized Estimate value of 0.503 , which means that every increase of one Corporate Entrepreneurship unit will have an impact on the supply chain management by $0.503 \%$. The results of this research are still relevant to the research result(Hassani, 2019);(Wahjudono, 2017)and(Pham et al., 2020)which proves that Corporate Entrepreneurship has a significant influence on Supply Chain Management.

2. H2: The result of testing the Effect of Organizational Culture on Supply Chain Management obtained a $\mathrm{CR}$ value of 2.840 and a $\mathrm{p}$-value of 0.005 .These values explain that the test results are sufficient to receive $\mathrm{H} 2$, namely the $\mathrm{CR}$ value which is already higher than the value of 1.96, and the p-value which is already lower than 0.05 .So it can be stated that the influence of organizational culture on supply chain management is significant.The coefficient of the influence of organizational culture on supply chain management can be seen from the model image and the Standardized Estimate value of 0.233 , which means that every time there is an increase in one organizational culture unit will have an impact on supply chain management by $0.233 \%$. The results of this research are still relevant to the research results(Porter, 2019); (Cao et al., 2015); (Cadden et al., 2013)and(Roh, Hong, \& Park, 2008)which states that organizational culture has a strong bond to the success of the Supply Chain Management strategy.

3. H3: The result of testing the effect of supply chain management on operational performance shows a CR value of 2.766 and a p-value of 0.006 .These values explain that the test results are sufficient to receive $\mathrm{H} 3$, namely the $\mathrm{CR}$ value which has been higher than the value of 1.96, and the p-value that has been lower than 0.05.So it can be stated that the effect of supply chain management on operational performance is significant.The coefficient of the influence of supply chain management on operational performance can be seen from the model image and the Standardized Estimate value of 0.288 , which means that every increase of one supply chain management unit will have an impact on operational performance by $0.288 \%$. The results of this research are still relevant to the research results found by(Miguel \& Brito, 2011);Pham et al, (2020);(Hassani, 2019); Akbar et al, (2014);(Porter, 2019); (Hashim et al., 2020); (Cadden et al., 2013); (Suharto \& Devie, 2013);(Suwanda \& Surjasa, 
International Journal of Business Management and Economic Review

Vol. 4, No. 04; 2021

ISSN: 2581-4664

2018)and(Miguel \& Brito, 2011)that is, supply chain collaboration directly affects logistics performance and operational performance.

4. H4: The result of testing the influence of Corporate Entrepreneurship on operational performance shows a CR value of 2.108 and a p-value of 0.035 . These values explain that the test results are sufficient to receive $\mathrm{H} 4$, namely the $\mathrm{CR}$ value which has been higher than the value of 1.96 and the p-value that has been lower than 0.05. So it can be stated that the effect of corporate entrepreneurship on operational performance is significant.The magnitude of the coefficient of corporate entrepreneurship influence on operational performance can be seen from the model image and the Standardized Estimate value of 0.201, which means that every increase in one corporate entrepreneurship unit will have an impact on operational performance by $0.201 \%$. The results of this research are still relevant to the research results(Chienwattanasook et al, 2019);(Wahjudono, 2017); (Hassani, 2019);(Otache \& Mahmood, 2015); Karacaoglu et al., (2012); and Mokaya, (2012) which revealed that there is a positive relationship between company entrepreneurship and business performance.

5. H5: The result of testing the Influence of Organizational Culture on Operational Performance shows a CR value of 3.423 and a p-value of *** or 0,000 .These values explain that the test results are sufficient to receive H5, namely the CR value which has been higher than the value of 1.96 and the $\mathrm{p}$-value that has been lower than 0.05.So it can be revealed that the influence of organizational culture on operational performance is significant.The coefficient of the influence of organizational culture on operational performance can be seen from the model image and the Standardized Estimate value of 0.281, which means that every time there is an increase in one organizational culture unit will have an impact on operational performance by $0.281 \%$. The results of this research are still relevant to the research results(Wahjudono, 2017); (Pham et al., 2020)and(Porter, 2019)which reveals that organizational culture plays an important role in creating the company's operational performance.Culture is a certain condition and situation or way of working that characterizes a company in carrying out its vision and mission.

\section{Indirect Effect (Mediation)}

The results of testing the indirect hypothesis (mediation) are described below:

1. H6: The influence of Corporate Entrepreneurship on operational performance through supply chain management. Testing the indirect effect hypothesis using the Sobel Test with the following results:

\begin{tabular}{|c|c|c|c|c|}
\hline Input: & & Test statistic: & Std. Error: & p-value: \\
\hline a 0.345 & Sobel test: & 2.41590198 & 0.07282994 & 0.01569629 \\
\hline$b 0.510$ & Aroian test: & 2.37898577 & 0.07396009 & 0.01736035 \\
\hline$s_{\mathrm{a}} 0.070$ & Goodman test: & 2.45459186 & 0.07168198 & 0.01410446 \\
\hline 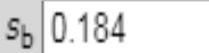 & Reset all & & Calculate & \\
\hline
\end{tabular}

Figure 4. Result of the First Mediation Hypothesis Test Corporate Entrepreneurship - Supply Chain Management - Operational Performance 
The picture above shows that the single statistical $t$ value is $2.415<1.96$ and the significance or p-value is $0.015<0.05$, so it is declared significant.Thus, it can be stated that supply chain management can mediate the effect of Corporate Entrepreneurship on operational performance partially (partial mediation) and significantly.In other words, accept $\mathrm{Ha}$ and reject Ho.The magnitude of the impact of supply chain management mediation on the influence of Corporate Entrepreneurship on operational performance can be determined by multiplying the unstandardizedvalue of the influence of Corporate Entrepreneurship on supply chain management and the influence of supply chain management on operational performance, namely $0.345 \times 0.510=0.176$.Thus, it can be stated that the influence of Corporate Entrepreneurship on operational performance can be partially mediated by supply chain management of $0.176 \%$. These results again reinforce the research results(Hassani, 2019); Pham et al, (2020); (Wahjudono, 2017)and(Chienwattanasook et al, 2019)which proves that the influence of Corporate Entrepreneurship on the company's operational performance is influenced by the supply chain management.

2. H7: The influence of organizational culture on operational performance through supply chain management.Testing the indirect effect hypothesis using the Sobel Test with the following results:

\begin{tabular}{|c|c|c|c|c|}
\hline Input: & & Test statistic: & Std. Error: & $p$-value: \\
\hline 0.161 & Sobel test: & 1.97832663 & 0.04150477 & 0.04789187 \\
\hline$b \quad 0.510$ & Aroian test: & 1.91803685 & 0.0428094 & 0.05510634 \\
\hline$s_{\mathrm{a}} 0.057$ & Goodman test: & 2.04468421 & 0.04015779 & 0.040886 \\
\hline$s_{\mathrm{b}} 0.184$ & Reset all & \multicolumn{3}{|c|}{ Calculate } \\
\hline
\end{tabular}

Figure 5. Result of the Second Mediation Hypothesis Test Organizational Culture - Supply Chain Management - Operational Performance

The picture above shows that the single statistical $t$ value is $1.978<1.960$ and the significance or p-value is $0.047<0.05$, so it is declared significant.Thus, it can be stated that supply chain management can mediate the influence of Corporate Entrepreneurship on operational performance partially and significantly.In other words, accept $\mathrm{Ha}$ and reject Ho.The magnitude of the impact of supply chain management mediation on the influence of organizational culture on operational performance can be seen by multiplying the unstandardizedvalue of the influence of organizational culture on supply chain management and the influence of supply chain management on operational performance, namely $0.161 \mathrm{x}$ $0.476=0.076$.Thus, it can be stated that the influence of organizational culture on operational performance is partially mediated by supply chain management of $0.076 \%$.This research supports the researchof (Porter, 2019)and(Pham et al, 2020). Supply chain performance was found to have a partial mediation in the relationship between corporate entrepreneurship and business performance, organizational culture \& business performance, 


\section{International Journal of Business Management and Economic Review}

Vol. 4, No. 04; 2021

ISSN: 2581-4664

management support \& business performance, organizational boundaries \& business performance and strengthening rewards and business performance.

\section{CONCLUSION}

Testing the research model on logistic companies in Banda Aceh, it concludes that corporate entrepreneurship significantly affects supply chain management, organizational culture significantly affects supply chain management, supply chain management significantly affects operational performance, corporate entrepreneurship significantly affects operational performance, organizational culture significantly affects operational performance, supply chain management mediates the influence of corporate entrepreneurship on operational performance, and supply chain management mediates the influence of organizational culture on operational performance. From these results, it also explains that supply chain management is proven to function as a partial mediator in the research model. These findings reveal that in modeling the operational performance of logistics companies, corporate entrepreneurship and organizational culture are the right predictor variables to be managed so that they can have an impact on increasing the effectiveness and efficiency of supply chain management and affect the increase in operational performance.

All of these findings can contribute to the development of further research where the modeling of test results can be a reference or a basis for further research.The novelty lies in the integration of previous theories of causality, which were tested in logistics companies.Further research is expected to add other variables such as Total Quality Management and self-efficacy of company employees in other industrial sectors. Several strategies for practitioners can be recommended from the results of this research, especially for logistics companies in Banda Aceh.Management needs to create Corporate Entrepreneurship or an entrepreneurial spirit in its employees through entrepreneurship education and training to increase their knowledge of the business processes they are working on.In addition, the dream must also respect employees who have innovative ideas and employees must often be involved in the decision-making process to hone their ability to solve problems that are often faced in the company so that it will create good Corporate Entrepreneurship and can help the company's operational performance.The organizational culture of logistics companies in Banda Aceh is still relatively low, this requires improvement in a better direction by accustoming employees to work with innovation and the courage to take risks, work seriously immediately without delaying work to avoid mistakes. Work professionally without levies outside company rules.

Sea transportation is still very minimal used to support logistics in Aceh, which in fact the safest and most cost-effective mode is the sea mode. In general, Aceh prioritizes land transportation modes which are certainly more expensive and a long process, so it is natural that the logistics price disparity in each region in Aceh is natural. Therefore, to maintain the suitability or disparity of logistics prices in Aceh, sea transportation modes need to be considered. In terms of making marine transportation effective, it requires special attention from regional leaders and related institutions in supporting and facilitating facilities and infrastructure for marine transportation modes such as quality docks or ports and road infrastructure for the distribution of logistics to locations. Simpler regulations for the available transportation modes also need to be considered, because with ease of logistics supply it will improve operational performance and company profitability, and when company profitability increases it will 


\section{International Journal of Business Management and Economic Review}

Vol. 4, No. 04; 2021

ISSN: 2581-4664

contribute to the region in terms of tax levies and reduce unemployment by creating jobs. by the private sector.

\section{REFERENCES}

Akbar, I., Muzaffar, M., \& Rehman, K. ur. (2014). Entrepreneurial Supply Chain Management Competence: Performance of Manufacturing Small and Medium Enterprises. International Journal of Management \& Organizational Studies, 1(2), 39-46. https://doi.org/10.2139/ssrn.2386969

Antoncic, B., \& Hisrich, R. D. (2003). Clarifying the intrapreneurship concept. Journal of Small Business and Enterprise Development, 10(1), 7-24. https://doi.org/https://doi.org/10.1108/14626000310461187

Baron, R. M., \& Kenny, D. A. (1986). The moderator-mediator variable distinction in social psychological research: Conceptual, strategic, and statistical considerations. Journal of Personality and Social Psychology, 51(6), 1173-1182. https://doi.org/10.1037//00223514.51.6.1173

Cadden, T., Marshall, D., \& Cao, G. (2013). Opposites attract: Organisational culture and supply chain performance. Supply Chain Management, 18(1), 86-103. https://doi.org/10.1108/13598541311293203

Cao, Z., Huo, B., Li, Y., \& Zhao, X. (2015). The impact of organizational culture on supply chain integration: A contingency and configuration approach. Supply Chain Management, 20(1), 24-41. https://doi.org/10.1108/SCM-11-2013-0426

Chienwattanasook, K., Wattanapongphasuk, S., Prianto, A. L., \& Jermsittiparsert, K. (2019). Corporate entrepreneurship and business performance of logistic companies in Indonesia. Industrial Engineering and Management Systems, 18(3), 541-550. https://doi.org/10.7232/iems.2019.18.3.541

Cooper, M. C., \& Ellram, L. M. (1993). Characteristics of Supply Chain Management and the Implications for Purchasing and Logistics Strategy. The International Journal of Logistics Management, 4(2), 13-24. https://doi.org/https://doi.org/10.1108/09574099310804957

Daft, R. L. (2010). New Era Of Management (9th ed.). Jakarta: Salemba Empat.

Dess, G. G., \& Lumpkin, G. T. (2005). The Role of Entrepreneurial Orientation in Stimulating Effective Corporate Entrepreneurship. Academy of Management Perspectives, 19(1), 147156. https://doi.org/https://doi.org/10.5465/ame.2005.15841975

Handoko, T. H. (2016). Manajemen personalia \& sumberdaya manusia (2nd ed.). Yogyakarta: BPFE.

Hashim, M., Baig, S. A., Amjad, F., Nazam, M., \& Akram, M. U. (2020). Impact of supply chain management practices on organizational performance and moderating role of innovation culture: A case of Pakistan textile industry. In Advances in Intelligent Systems and Computing (Vol. 1002). https://doi.org/10.1007/978-3-030-21255-1_30

Hassani, A. (2019). the Impact of Entrepreneurial Orientation and Entrepreneurial Strategy on 


\section{International Journal of Business Management and Economic Review}

Vol. 4, No. 04; 2021

ISSN: 2581-4664

Sustainable Supply Chain Management and Organizational Performance. International Journal of Business Research, 19(2), 13-22. https://doi.org/10.18374/ijbr-19-2.2

Heizer, J., \& Render, B. (2015). Manajemen operasi : manajemen keberlangsungan dan rantai pasokan. London: Pearson.

Kazanjia, R. K., Drazin, R., \& Glynn, M. A. (2017). Implementing Strategies for Corporate Entrepreneurship: A Knowledge-Based Perspective. In M. A. Hitt, R. D. Ireland, S. M. Camp, \& D. L. Sexton (Eds.), Strategic Entrepreneurship: Creating a New Mindset (pp. 173-199). https://doi.org/https://doi.org/10.1002/9781405164085.ch9

Luthans, F. (2013). Organizational Behavior An Evidence-Based Approach (8th ed.). New York: Mc Graw Hill.

Miguel, P. L. de S., \& Brito, L. A. L. (2011). Supply Chain Management measurement and its influence on Operational Performance. Journal of Operations and Supply Chain Management, 4(2), 56. https://doi.org/10.12660/joscmv4n2p56-70

Mwaniki, P., \& Ondiek, C. O. (2018). Evaluation of the Effects of SaaS on SMEs in Nairobi County, Kenya. Journal of Information Systems Engineering and Management, 3(3), 1-11. https://doi.org/https://doi.org/10.20897/jisem/2656

Otache, I., \& Mahmood, R. (2015). Corporate entrepreneurship and business performance: The role of external environment and organizational culture: A proposed framework. Mediterranean Journal of Social Sciences, 6(4S3), 524-531. https://doi.org/10.5901/mjss.2015.v6n4s3p524

Pham, H. Van, Nguyen, H. X., \& Huy, D. T. N. (2020). Impact of corporate entrepreneurship and organizational culture on business performance: The role of supply chain management. International Journal of Supply Chain Management, 9(3), 1072-1079.

Porter, M. G. (2019). Supply chain integration: Does organizational culture matter? Operations and Supply Chain Management, 12(1), 49-59. https://doi.org/10.31387/oscm0360222

Rachbini, W. (2016). Supply Chain Management dan kinerja perusahaan. Jurnal Riset Manajemen Dan Bisnis, 7(1), 23-30. https://doi.org/10.36226/jrmb.v1i1.7

Rahadi, D. R. (2012). Pengaruh Supply Chain Management Terhadap Kinerja Operasional Perusahaan. Proceeding Seminar Sistem Produksi X. Bandung: Laboratorium Sistem Produksi, Program Studi Teknik Industri, Institut Teknologi Bandung.

Robbins, S. P., \& Judge, T. A. (2017). Essential of Organisational Behaviour (14th ed.). New Jersey: Pearson.

Roh, J. J., Hong, P., \& Park, Y. (2008). Organizational culture and supply chain strategy: a framework for effective information flows. Enterprise Information Management, 21(4), 361-376. https://doi.org/10.1108/17410390810888651

Simchi-Levi, D., Kaminsky, P., \& Simchi-Levi, E. (2004). Designing and Managing The Supply Chain: Concepts, Strategies, and Case Studies. Boston: McGraw-Hill.

Suharto, R., \& Devie. (2013). Analisa Pengaruh Knowledge Management Terhadap Keunggulan 
International Journal of Business Management and Economic Review

Vol. 4, No. 04; 2021

ISSN: 2581-4664

Bersaing dan Kinerja Perusahaan. Business Accounting Review, 1(2), 161-171.

Suwanda, A., \& Surjasa, D. (2018). Pengaruh Kolaborasi Rantai Pasok Terhadap Kinerja Keuangan Melalui Kinerja Logistik, Kinerja Operasional Dan Kepuasan Pelanggan (Studi Empiris Pada Perusahaan-Perusahaan Ritel Yang Beroperasi Di Indonesia). Riset Dan Karya Ilmiah, 3(1), 1. https://doi.org/10.25105/pdk.v3i1.2474

Wahjudono, D. B. K. (2017). Intangibles Resources and Corporate Performance: the Role of Corporate Entrepreneurship As Mediator and Entrepreneurial Action As Moderator. Jurnal Aplikasi Manajemen, 15(2), 330-338. https://doi.org/10.21776/ub.jam.2017.015.02.17

Wibowo. (2016). Manajemen Kinerja (kelima). Jakarta: PT. Rajagrafindo Persada. 